\title{
Analysis of the Energy Scenario of Bangladesh in Current, SDG 2030 and Vision 2041
}

\author{
Mahadehe Hassan \\ Hydrocarbon Unit (HCU), Energy and Mineral Resources Division, Ministry of Power, Energy and Mineral Resources, Dhaka, Bangladesh \\ Email address: \\ mahadehe@hcu.org.bd

\section{To cite this article:} \\ Mahadehe Hassan. Analysis of the Energy Scenario of Bangladesh in Current, SDG 2030 and Vision 2041. Journal of Energy, Environmental \\ \& Chemical Engineering. Vol. 6, No. 3, 2021, pp. 45-56. doi: 10.11648/j.jeece.20210603.11
}

Received: June 23, 2021; Accepted: July 8, 2021; Published: July 22, 2021

\begin{abstract}
The main concern of a country is energy in the present world. Developing country like Bangladesh is also facing challenges to meet its energy demand. For energy, Bangladesh mainly depends on Natural gas, Petroleum Oil, LPG, LNG, Coal, NGL etc. It seems that average increase of energy consumption in Bangladesh about $6 \%$ per annum. Therefore, this study analyzes current energy scenario and visualization of future energy of Bangladesh in accordance with SDG 2030 and Vision 2041. The research focuses on the following points: i) What is the current consumption of total energy in MTOE and the Per capita consumption of energy in Kgoe (Kilogram Oil Equivalent) and per capita generation of electricity in Bangladesh (kWh). ii) What is the approximate consumption of total energy in MTOE, and what will be Per capita consumption of energy in Kgoe (Kilogram Oil Equivalent) and per capita generation of electricity in Bangladesh (kWh) by 2030. iii) What is the approximate consumption of total energy in MTOE, and what will be Per capita consumption of energy in Kgoe (Kilogram Oil Equivalent) and per capita generation of electricity in Bangladesh $(\mathrm{kWh})$ by 2041.
\end{abstract}

Keywords: Natural Gas, LPG, LNG, Oil, Coal, Renewable Energy, Electricity, Biomass, Energy Mix

\section{Introduction}

Bangladesh is a mid-income country. Her GDP growth rate is one of the world's largest. For any country, development is the precondition for continued growth of GDP. And the main driving force of the country's development is energy. Proper use of energy is essential to meet the country's growing energy demands as well as to lift up from a mid-income country to a developed country. Energy is playing a vital role in implementing Vision-2121, Vision-2041 and achieving Sustainable Development Goals primary energy consumption per GDB $15 \%, 25 \%$ and $20 \%$ improvement [7].

In Bangladesh, about 62 percent of energy demand is met from natural gas [6]. Among other fuels- oil, coal, biomass etc. are vital. There is a huge reserve of coal in our country, but coal is less produced as well as less used here. On the other hand, natural gas reserve is not that substantial, but its production and consumption are the highest among the available resources. Besides those, energy demand is being met through imported oil and LPG. Moreover, the government has already started importing LNG to meet increasing gas demand. Biomass is being used as a lion's share of energy. The energy demand is also being met by importing electricity from India.

The use of renewable energy instead of gas, coal and oil has been started in the whole world and is essential for sustainable development and keeping up with the environment by preventing carbon emissions. Many countries in the world like Sweden, Germany, China and USA are currently using renewable energy as a significant part of their energy demand. Bangladesh is also using renewable energy, but it's very less than necessity. The government has taken various steps to increase the use of renewable energy in the future, including solar home system, solar irrigation system, Rooppur Nuclear Project, etc.

Development of energy sector is the key factor for continued development of the country. Bangladesh needs to emphasize on the new exploration activities using latest techniques to explore new mines. Apart from reducing dependence on natural gas, it needs to be coordinated with the imported LNG and enhance the percentage of usage oil and LPG; thereby Bangladesh will succeed in reaching its desired goal of development. 


\section{Current Position of Energy Resources of Bangladesh}

Known commercial energy resources in Bangladesh include indigenous natural gas, coal, imported oil, LPG, imported LNG, imported electricity and hydro-electricity. Biomass accounts for about $27 \%$ of the primary energy [7] and the rest $73 \%$ is being met by commercial energy. Natural gas accounts for about $62 \%$ of the commercial energy (with $8 \%$ imported LNG). Imported oil accounts for the lion's share of the rest. In this year, Bangladesh imports about 8.5 million metric ton of crude and refined Petroleum Products. Apart from natural gas and crude oil, coal is mainly used as fuel in the brick-fields and Thermal Power Plant [15].

Moreover, power is also generated by capitalizing Solar
Home System (SHS) in on-grid and off grid areas. The amount of power generation using solar system is currently about 401.26 MW [11]. In addition, there are some poultry and dairy farms in which bio-gas plants are being set up and this bio-gas is used for cooking and power generation. The amount of power generation from such plants is currently about $1.03 \mathrm{MW}$. Steps have been taken to generate electricity by Bio-Mass Gasification Method in the country.

Actual final consumption of total energy is around 55.50 MTOE (Table 1). Average increase of energy consumption is about $6 \%$ per annum. Per capita consumption of energy in Bangladesh is on an average 332.34 Kgoe (Kilogram Oil Equivalent) and per capita generation of electricity is 428 $\mathrm{kWh}$ with an access to electricity $97 \%$, which is lower than those of South Asian neighboring countries.

Table 1. Energy Calculation for 2019-2020 (MTOE).

\begin{tabular}{llll}
\hline Name & Unit & Quantity & Mtoe \\
\hline Oil (Crude + Refined) & K ton & 8234 & 8.23 \\
LPG & K ton & 854 & 0.85 \\
Natural Gas & Bcf & 886.93 & 20.56 \\
LNG & Bcf & 202.88 & 4.70 \\
Coal (Imported) & K ton & 6828 & 4.32 \\
Coal (Local) & K ton & 808 & 0.51 \\
RE (Hydro) & MW & 230 & 0.17 \\
RE (Solar+wind) & MW & 417.51 & 0.31 \\
Electricity (Imported) & MW & 1160 & 0.86 \\
Total Commercial & & & 40.52 \\
Biomass & & & 14.99 \\
Total primary & & & 55.50 \\
\hline
\end{tabular}

Source: HCU Data Bank

Energy calculation for 2019-20. (MTOE)

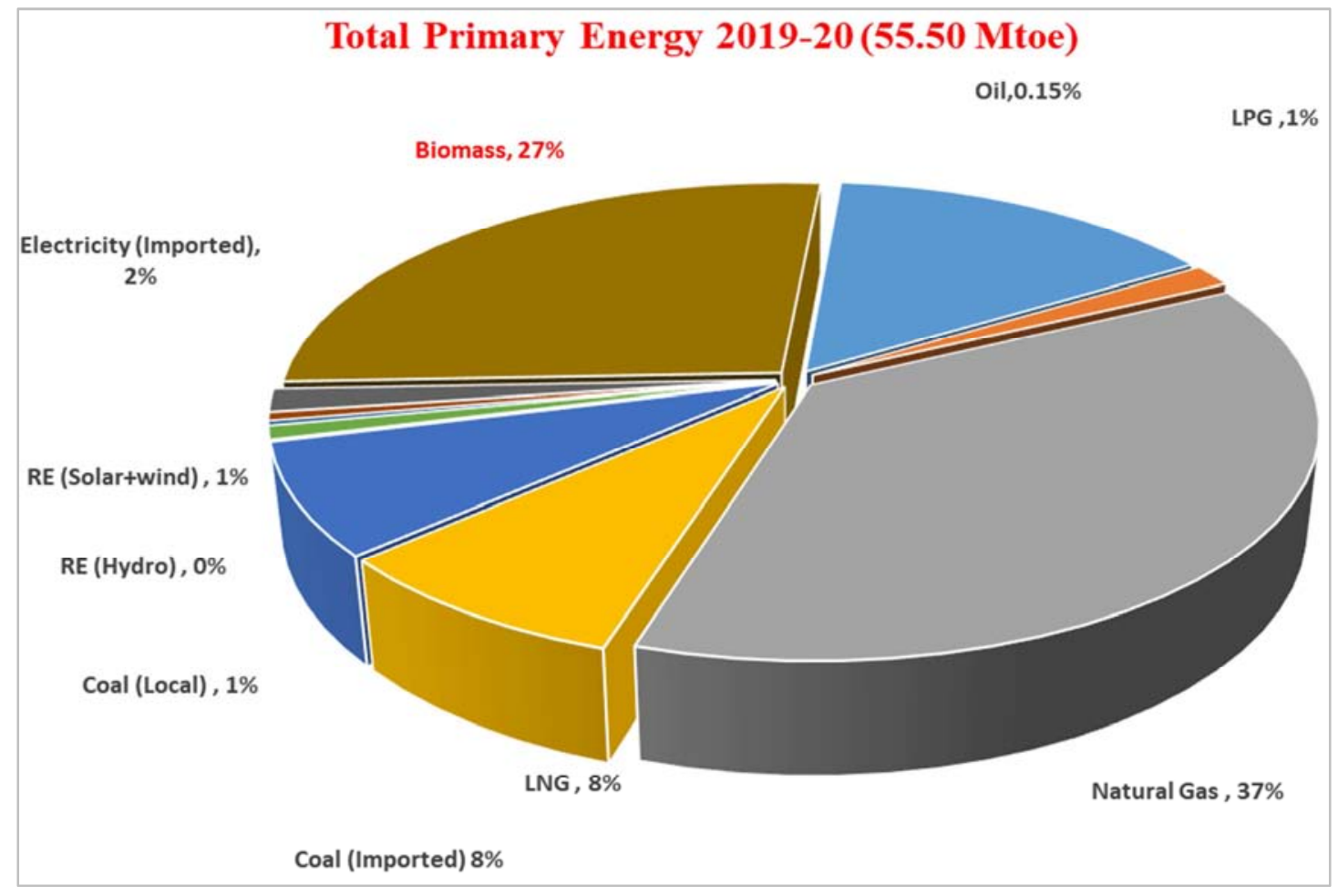

Figure 1. Share of Total Primary Energy (2019-20). 


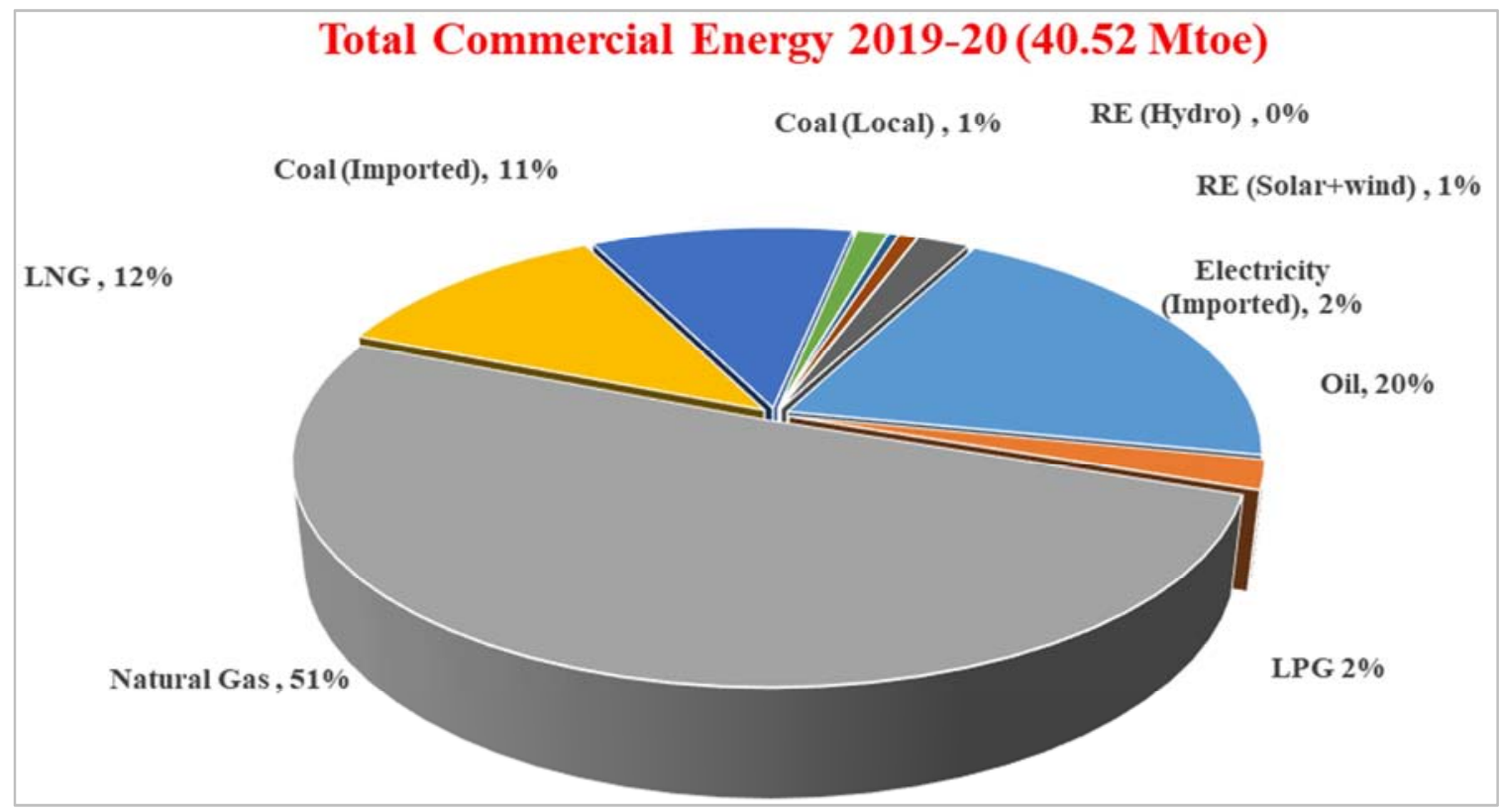

Figure 2. Share of Total Commercial Energy (2019-20).

Bangladesh also has a bright potential to produce electricity from wind and mini-hydro. Recently, solar power based irrigation pump has been used in a number of areas of the country. Its wide use will lessen the pressure on diesel and electricity

\subsection{Natural Gas Reserve}

Since first discovery in 1955 as of today 26 gas fields, 24 in the onshore and 2 in the offshore have been discovered in the country [1]. Of them 20 gas fields are in production, one offshore gas field have depilated after 14 years of production while other offshore field has not been viable for production due to small reserve. The estimated proven plus probable recoverable reserve was 40.09 Tcf $[3,4,16]$. As of March 2021, a total of 18.46 Tcf gas has already been produced leaving only $11.59 \mathrm{TCF}$ recoverable reserve in proven plus probable category [18]. Some key information about the historical natural gas production 2008-2020 sector is presented in the below:

\section{Historical Production of Gas (2008-09 to 2019-20) and LNG Import} (2018-19 to 2019-20) in Bcf

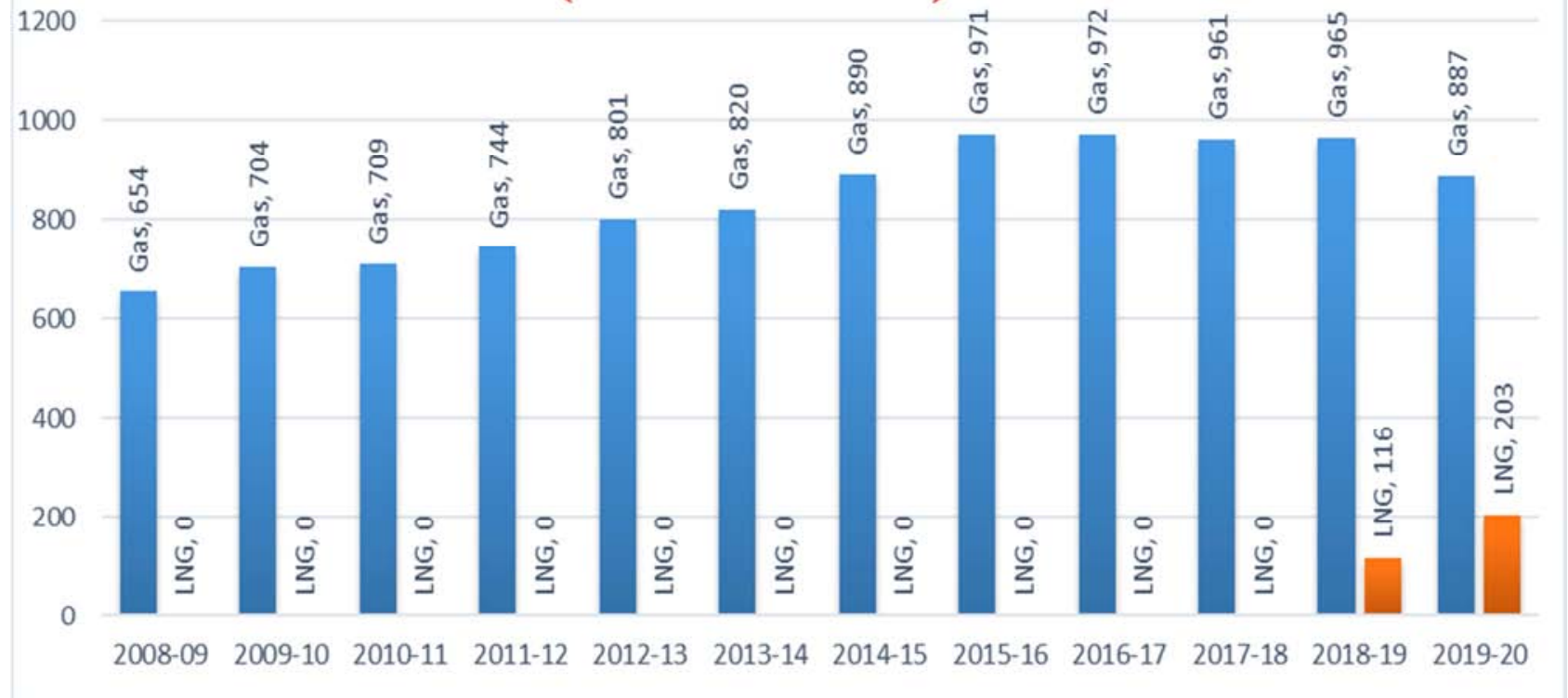

Source: HCU Data Bank

Figure 3. Historical Production of Gas and Import LNG. 
Although natural gas was introduced as commercial fuel in early 1960s, [1] its consumption got real momentum in eighties marking the beginning of the industrialization in the country

\subsection{Natural Gas Consumption}

The current average production of natural gas is about 2978 MMcfd. A total 994 billion cubic feet (BCF) of natural gas was produced in 2019-20 (including LNG) which was used by power $46 \%$, fertilizer $5 \%$, captive power $15 \%$, industry $16 \%$, domestic $13 \%, \mathrm{CNG} 4 \%$ and others very small amount [17]. Natural gas accounts for the $71.82 \%$ grid electricity generation while all the 7 urea fertilizer factories are dependent on natural gas for feedstock. Natural gas has made tremendous contribution towards industrial growth in the country as fuel for heating and captive power generation at very favorable price. While the whole nation has been benefitted by this resource, about $13 \%$ of the populations have directly been benefitted by using piped natural gas for household purposes. Compressed Natural Gas is being used as automobile fuel by about 504,293 motor vehicles in the country. Expansion of $\mathrm{CNG}$ facilities early last decade dramatically improved air quality in large cities especially in the capital Dhaka as well as lot amount of foreign exchange has been saved due to less amount of oil import.

Piped natural gas for household purposes. Compressed Natural Gas is being used as automobile fuel by about 504,293 motor vehicles in the country. Expansion of CNG facilities early last decade dramatically improved air quality in large cities especially in the capital Dhaka as well as lot amount of foreign exchange has been saved due to less amount of oil import.

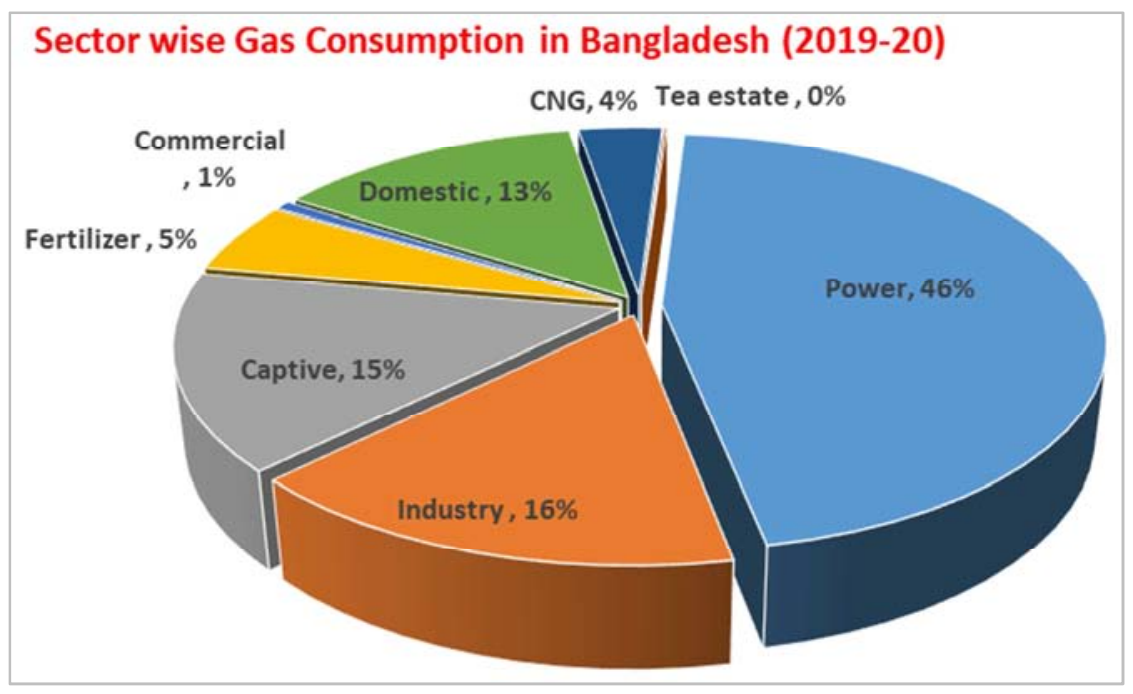

Figure 4. Sector wise Gas Consumption in Bangladesh (2019-20).

\subsection{Natural Gas Demand}

Being almost single indigenous sources of commercial energy demand for natural gas experienced vary fast growth over the last three decades often outstripping the supply. Present demand for gas in the country is about 3508 MMscfd whereas supply is 2978 MMscfd (Gas + imported LNG) indicating a shortage of about $530 \mathrm{MMscfd}$. It is estimated that demand for natural gas will rise to about 4622 MMscfd by the 2030. Natural gas demand and supply projection in the country is shown in the below [2]:

Table 2. Natural Gas Supply \& Demand (MMCFD) [2]

\begin{tabular}{lll}
\hline Year & Total Demand & Total Supply \\
\hline 2019 & 3392 & 3331 \\
2020 & 3508 & 3477 \\
2021 & 3624 & 3500 \\
2022 & 3911 & 3769 \\
2023 & 4048 & 3915 \\
2024 & 4075 & 4061 \\
2025 & 4130 & 4300 \\
2026 & 4207 & 4350 \\
2027 & 4373 & 4400 \\
\hline
\end{tabular}

\begin{tabular}{lll}
\hline Year & Total Demand & Total Supply \\
\hline 2028 & 4531 & 4450 \\
2029 & 4561 & 4500 \\
2030 & 4622 & 4600 \\
\hline
\end{tabular}

\subsection{LNG Import}

To meet the growing energy demand of the country, the government initiated the import of LNG from abroad in August 2018. Cumulative LNG imported 318.77 Bcf from August 2018 to June 2020. At present, a total of $1000 \mathrm{MMcfd}$ LNG has been added to the national grid [12].

\subsection{Liquefied Petroleum Gas (LPG)}

Demand of Liquefied Petroleum Gas (LPG) in Bangladesh is very high. In the public sector $13,414 \mathrm{MT}$ is produced during 2019-20 FY whereas 835,027 MT is imported thru private entity. Therefore, public and private sector combining do the marketing of 848,441 MT of LPG in 2019-20, which is meeting a certain portion of LPG demand of the country. Some key information about the last five years LPG production and Import is presented in the below [13]: 
Table 3. LPG scenario of last 5 year (MT).

\begin{tabular}{llll}
\hline Year & Production & Import & Total \\
\hline $2014-15$ & 17,574 & 110,000 & 127,574 \\
$2015-16$ & 14,000 & 172,792 & 186,792 \\
$2016-17$ & 16,382 & 307,000 & 323,382 \\
$2017-18$ & 15,936 & 537,686 & 553,622 \\
$2018-19$ & 19,228 & 681,036 & 700,264 \\
$2019-20$ & 13,414 & 835,027 & 848,441 \\
\hline
\end{tabular}

Source: HCU Data Bank

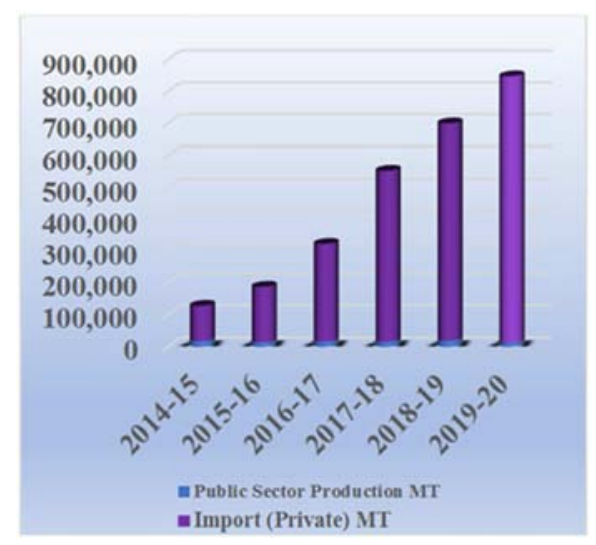

Figure 5. LPG Public and Private Scenario in Bangladesh.

\subsection{Supply and Consumption of Oil}

Petroleum products viz. diesel, petrol, octane furnace oil etc., account for about $20 \%$ commercial energy supply in the country. Liquid fuel used in Bangladesh is mostly imported. Locally produced gas condensate shares only $6 \%$ of total liquid fuel consumption. Bangladesh imports about 1.26 million metric tons of crude oil along with 4.04 million metric tons (approx.) of refined petroleum products per annum. About 0.52 million metric tons per year locally produced gas condensate, which is fractionated mainly into petrol, diesel and kerosene, is the only domestic source of liquid fuel. Major consumer of liquid fuel is transport followed by power, agriculture, industry and commercial sectors.

Some key information about 2019-2020 is presented in the sector-wise consumption of petroleum products in the below [13]:

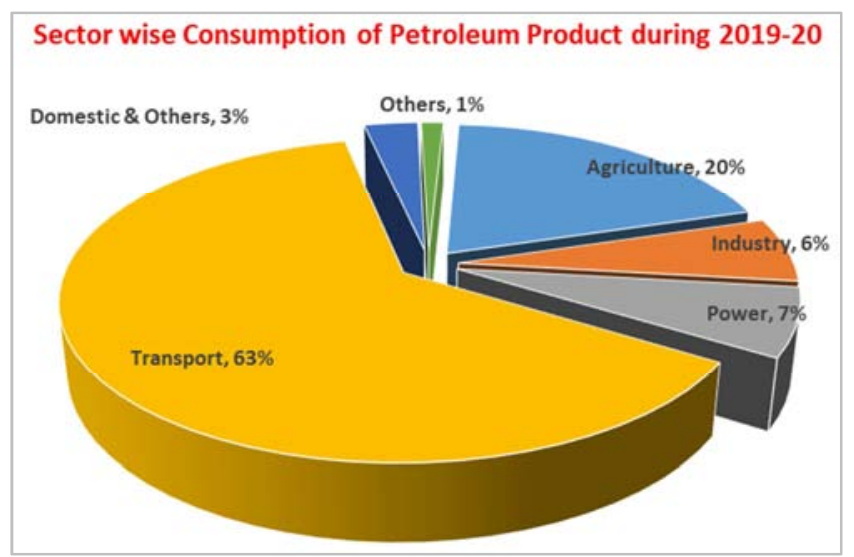

Figure 6. Sector wise consumption of petroleum products in Bangladesh (2019-20).
Diesel is the dominant liquid fuel used in the country. Petroleum products used during last five years are shown in the below [13]:

Table 4. Sale of Petroleum Products during last 5 Years (MT).

\begin{tabular}{llllll}
\hline Products & $\mathbf{2 0 1 5 - 1 6}$ & $\mathbf{2 0 1 6 - 1 7}$ & $\mathbf{2 0 1 7 - 1 8}$ & $\mathbf{2 0 1 8 - 1 9}$ & $\mathbf{2 0 1 9 - 2 0}$ \\
\hline Octane & 147557 & 186911 & 230280 & 266988 & 262943 \\
Petrol & 137360 & 232359 & 284668 & 318593 & 321940 \\
Diesel & 3606404 & 4000044 & 4835712 & 4593486 & 4015633 \\
Kerosene & 213685 & 170993 & 138403 & 121497 & 106195 \\
Furnace Oil & 711889 & 806440 & 925150 & 683725 & 362713 \\
Jet A-1 & 347323 & 376700 & 408272 & 429951 & 350605 \\
Others & 91802 & 115283 & 125851 & 129982 & 68639 \\
Total & 5256020 & 5888730 & 6948336 & 6544222 & 5488668 \\
\hline
\end{tabular}

Source: HCU Data Bank

Demand for petroleum products is growing at the rate of 2 to $4 \%$ per year. If this trend continues demand for oil will increase to about 8 million tons by the year 2030 [5].

\subsection{Coal}

Energy is the main indicator of economic growth for a country and constitutes one of the vital infrastructural inputs in socio-economic development. At present, natural gas is the main indigenous primary energy source of Bangladesh. Several studies reveal that domestic production of natural gas will be depleting soon in the near future. Considering the uncertainty of sustainable supply of primary energy, it is imperative to diversify the primary energy sources in the country. In that case, domestic coal can be a major alternative energy source for the energy security of the country. At present $2.55 \%$ of electricity has been produced from domestic coal [18]. Five coal fields so far discovered, namely Barapukuria, Khalaspir, Phulbari, Jamalganj and Dighipara. If initiatives are taken for exploration all over the country, there are enough possibilities to discover more coal mines. Out of the discovered mines, coal from 4 deposits (118-509 meters) is extractable at present. Production from Jamalganj may not be viable with present day's technology due to the depth of the deposits. The amount of coal reserves in Bangladesh coal fields are shown in the below:

Table 5. Coal Fields of Bangladesh (MT).

\begin{tabular}{lll}
\hline Place/Field (Discovery Year) & Reserve & Calorific Value (BTU/lb) \\
\hline Barapukuria, Dinajpur (1985) & 390 & 11,040 \\
Khalaspir, Rangpur (1995) & 523 & 12,700 \\
Phulbari, Dinajpur (1997) & 572 & 11,900 \\
Jamalganj, Jaipurhat (1965) & 1,054 & 11,000 \\
Dighipara, Dinajpur (1995) & 600 & 13,090 \\
& Total=3139 \\
\hline
\end{tabular}

Source: HCU Data Bank

Coal might be the alternative fuel to natural gas. These coals can conveniently meet the energy needs of Bangladesh for 50 years. It is notable that the coal of Bangladesh is considered to be high quality in terms of its high level of heat generation capacity as well as low Sulphur content. Some key 
information about the last five years Coal production and Import is presented in the below:

Table 6. Coal scenario of last 5 year (MT).

\begin{tabular}{llll}
\hline Year & Production & Import (Private) & Total \\
\hline $2014-15$ & $675,775.50$ & $1,812,030$ & $2,487,806$ \\
$2015-16$ & $1,021,638$ & $3,812,060$ & $4,833,698$ \\
$2016-17$ & $1,160,657.81$ & $2,801,407$ & $3,962,065$ \\
$2017-18$ & $923,276.00$ & $3,394,534.24$ & $4,317,810$ \\
$2018-19$ & $803,315.00$ & $5,754,025$ & $65,57,339$ \\
$2019-20$ & 808,358 & $6,828,032$ & $7,636,390$ \\
\hline
\end{tabular}

Source: HCU Data Bank

Commercial production of Barapukuria Coal Mine commenced from 10 September 2005 using underground mining method with the targeted capacity of one million metric tons per year. Almost $65 \%$ of the production is being used by $250 \mathrm{MW}$ ( 2 x $125 \mathrm{MW}$ ) Coal fired power station operated by Power Development Board of Bangladesh near Barapukuria coal mine [18]. Remaining 35\% coal is being used in brick fields and other domestic purposes which have an impact of reducing deforestation. A total of 808,358 MT 10.75 million metric ton of coal has been extracted in the FY 2019-20 [12] and 6,828,032 MT has been imported [15]. As a result, 7,636,390 MT coal has been consumed in this FY.

Out of these 5 coal fields, Petrobangla has developed the first and only coal mine of the country at Barapukuria. Commercial production started from September 2005 and currently this mine is producing 3,000-3,500 metric tons of coal per day. From the beginning of the mine total 11.39 million metric tons of coal has been produced till December, 2019. In the year 2019, total 0.908 million metric tons of coal has been produced and the entire amount of produced coal are being used to operate the Barapukuria $525 \mathrm{MW}$ coal fired power plant.

\subsection{Peat}

The peat deposits of Bangladesh are located in the low lying areas of the alluvial plain which are generally submerged under water for a large period each year. Peat occurs in Baghia-Chanda beel under Madaripur and Gopalganj district, Kola Mouza of Khulna district, Chatal beel area of Moulavibazar district, Pagla, Dirai and Shalla area of Sunamganj district, Chorkai area of Sylhet district, Brahmanbaria Sadar upazila of Brahmanbaria district and Mukundapur area of Habiganj district. It has a carbon content of $50-60 \%$ and has a calorific value between $5500 \mathrm{Btu} / \mathrm{lb}$. and $7000 \mathrm{Btu} / \mathrm{lb}$ [9]. The peat occurs at the surface or at shallow depths below the surface. The total peat reserve (dry peat) discovered in Bangladesh is 146.36 million tons. There is no commercial utilization of peat in Bangladesh at present. Peat can be conveniently used in the form of briquette, ovoid and compressed tablets as an alternative fuel to household work, in brick and lime industries and in small capacity thermal power plant $(10 \mathrm{MW})$ in rural areas. Three exploration licenses of peat is granted in Rajoir Upazila of Madaripur and Kotalipara
Upazila of Gopalganj district.

\subsection{Condensate and Natural Gas Liquids (NGL)}

Some of the gas fields located in north - eastern part of Bangladesh contains high percentage of liquid hydrocarbon. Extraction of this liquid, especially value added by-products, is becoming a growing activity. Apart from the condensate fractionation plant installed in different gas fields, Rashidpur Condensate Fractionation Plant with a capacity of 3,700 bbl./day is producing petrol, diesel and kerosene by fractioning the condensate received from Bibiyana Gas Field. During 2019-20, a total of 453,863.35 barrels of condensate was produced by SGFL, BGFCL and BAPEX and $3,384,009.59$ barrels by IOCs as a by-product of gas [12]. During the same period, SGFL, BGFCL and BAPEX extracted 22,110,000 liter or 139,068 barrels of NGL from the gas processed at its Mole-Sieve Turbo Expander plant at Kailashtila. On the other hand, a total of $187,861,463$ liter of petrol, 43,369,875 liter of diesel and 23,268,332 liter of kerosene was produced by fractionating the condensate at the fractionation plants located at different fields of SGFL, BGFCL and BAPEX [12].

\section{Future Plans for the Implementation of SDGs 2030 and Vision 2041}

\subsection{Natural Gas}

Natural gas production will be 1671 MMcfd and 1684 MMcfd in 2030 and 2041 [8] therefore, to various steps have been taken in the Natural gas production increase, which will play a significant role in the SDGs of the energy Sector and the implementation of the Government's Vision-2041

(a) Exploration Activities

1) Two projects of 2D seismic survey funded by the Gas Development Fund have been undertaken to explore remaining possibilities of Bengal for deep hydrocarbongeological province in the least explored region of the country through $2 \mathrm{D}$ seismic survey.

2) $3 \mathrm{D}$ seismic data collected in Fenchuganj and Rupganj gas fields in 2018-19 field-season will be used to identify new locations for better drilling well in the exploration gas fields.

3) Moreover, a joint study was conducted with Mitsui Oil Exploration Company Ltd. (MOECO), Japan and BAPEX to explain 20 possible leads and prospects in block $8 \& 11$. Drilling will be done there based on the results of that study.

b) $2 D$ seismic Survey Activities:

1) To detect the place of exploratory able wells drilling under the scope of project titled Rupkalpa-9: 2D Seismic Project" financed by gas development fund (GDF), 2,190 km 2D seismic data have been collected during the year in Kishoreganj, Narsingdi, Tangail, Gazipur, Netrokona, Jamalpur, Sherpur and Sunamganj districts.

2) $2 \mathrm{D}$ seismic survey have been carried out over the 
exploration blocks $3 \mathrm{~B}, 6 \mathrm{~B}$ and 7 under the project of "2D Seismic Survey Over Exploration Blocks 3B, 6B and 7" with the financed of the gas development fund (GDF) by an international seismic

(c) 3D Seismic Survey Activities:

3D Seismic Project of BAPEX" financed by GDF. A total of 2,450 sq. kms 3D seismic survey has been completed so far under this project. Data analysis activities of Fenchuganj Gas Field and data processing work of Rupganj gas field is in progress.

(d) Drilling Activities:

To increase gas production, SDG and to implement the Government's Vision-2041 Rupkalpa-1 under drilling wells of Srikail East-1 and Salda North-1, Rupkalpa-2 under drilling Semutang South-1 and Zakiganj-1 exploratory wells, Rupkalpa-3 under drilling of Kasba-1 and Madarganj-1 exploration wells and Rupkalpa-5 under drilling of Begumganj-4 appraisal/development well and Begumganj-3 workover Rupkalpa-1,2,3 \& 4 Drilling Projects financed by the Gas Development fund (GDF) for implementation of drilling activities and approved by the Energy and Mineral Resources Division.

(e) Workover Activities:

To increase gas production, Workover work will be done at Begumganj-3 well, Titas-6 well and Narsingdi-1 well under the Rupkalpa-5 drilling project to. To implement SDG and the Government's Vision-2041.

(f) Offshore Activities:

1) Block SS-11 (Santos-Kris-Bapex): $3,146 \mathrm{~km} \mathrm{2D} \mathrm{seismic}$ survey and 305 sq. km 3D seismic survey will be conducted.

2) A total of 5,081-line $\mathrm{km} 2 \mathrm{D}$ seismic survey after completing the data analysis at the end of 2 drilling locations have been assigned to SS-04 and 1 to SS-09.

3) Block DS-12 (POSCO-Daewoo): 5 probable leads were identified after analyzing 3,580 km 2D Seismic Survey. $2 \mathrm{D}$ seismic data processing is currently underway to gain a better understanding of the identified leads. Based on this, the next 1000 sq. km. 3D seismic survey will be done.

\section{3..2 Exploration of Unconventional form of Energy}

To various steps have been taken to Exploration of Unconventional form of energy which will play a significant role in the SDGs of the energy Sector and the implementation of the Government's Vision-2041

1) A project has been undertaken to assess the potentiality of coal bed methane in Jamalganj coal deposit, the largest and deepest coal deposit in the country.

2) Exploration of different form of Unconventional energy like Coal Bed Methane (CBM), Shale gas, Underground Coal Gasification (UCG) is going on in search of alternate energy have been undertaken.

\subsection{LNG import}

To various steps have been taken to import 2000 MMcfd
LNG in 2030 and 2041 which will play a significant role in the SDGs of the energy Sector and the implementation of the Government's Vision-2041 [8].

(a) Floating LNG Terminal

1) Action has been taken to set up a BOOT basis to install 500 MMcfd capacity floating LNG terminal in Kutubdia

2) To set up 500 MMcfd capacity FSRU and Fixed Jetty Based LNG Receiving Terminal in Kutubdia Honkong Shanghai Manjala Power Ltd. Co. (HSMPL) with Global LNG \& Petronas on BOOT basis has been undertaken activities

(b) Land Based LNG Terminal

1) Feasibility study project on the $1000 \mathrm{MMcfd}$ capacity land based LNG Terminal in Maheshkhali has been under taken.

2) To set up a 1000 MMcfd land based LNG terminal at Kutubdia by Petronet India Limited has been under taken.

3) Feasibility study project for setting up a land based LNG terminals in Payra port, rest of Kutubdia and Maheshkhali area has been undertaken.

\subsection{Oil}

Considering the rising demand for oil the government has been under taken various projects to market more imported oil which will play a significant role in the SDGs of the energy Sector and the implementation of the Government's Vision-2041

1) Capacity Enactment Projects $2^{\text {nd }}$ Unit ERL

2) Single Point Mooring (SPM) project

3) India-Bangladesh Friendship pipeline (IBFPL).

4) Installation of Custody Transfer Flow Meter at ERL Tank firm.

5) Terminal Automation of marketing companies of BPC.

Establishment of LPG terminal by BPC in Maheshkhali-Matarbari area of Cox's Bazar district.

\subsection{Liquefied Petroleum Gas (LPG)}

Considering the rising demand for LPG, government has decided to enhance LPG bottling facilities for marketing more imported LPG. For this purpose, two LPG bottled plants, each having capacity of 100 thousand MT per annum, have been set up in the coastal areas which will play a significant role in the SDGs of the energy Sector and the implementation of the Government's Vision-2041

\section{Result and Discussion}

\subsection{Current Primary Energy Mix for Power Generation}

As of June 2020, the total power generation capacity combining public and private sector was $23,548 \mathrm{MW}$, leaving $20 \%$ capacity for maintenance and forced outage, available generation capacity should be about 18,838 MW without fuel constraint. 
Maximum generation actually obtained till 30 June 2020 was $12,738 \mathrm{MW}$, which was less than 18,838 MW [11]. It might have occurred due to fuel supply constraint. Of the total generation capacity, distribution between public sector and private sector entities are $52 \%$ and $43 \%$ respectively and from import 5\%. Bangladesh has started importing $500 \mathrm{MW}$ electricity from India (started in October 2013) additional 100 MW from March'16 and 560 MW from December 2018 which contributed $9 \%$ of total power generation

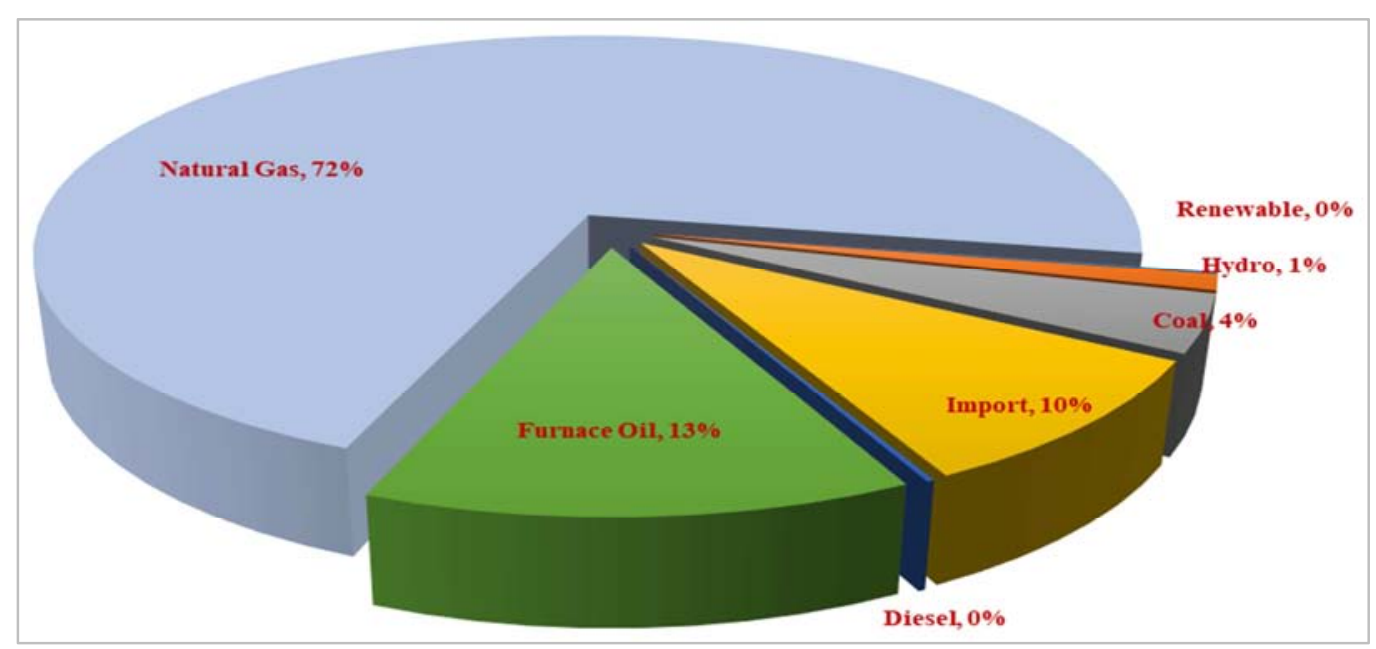

Figure 7. Power Generation by fuel in Bangladesh (2019-20) [11].

The composition of primary energy mix for power generation in FY 2019-20 is shown in Figure above. Of the total electricity generated in $2019-20,77 \%$ was generated from domestic fuels (Natural Gas, Coal \& Hydro) and 13.44\% from imported petroleum fuels (Diesel and Furnace oil) and 9.34\% was electricity Import from India as cross border energy trade [11].

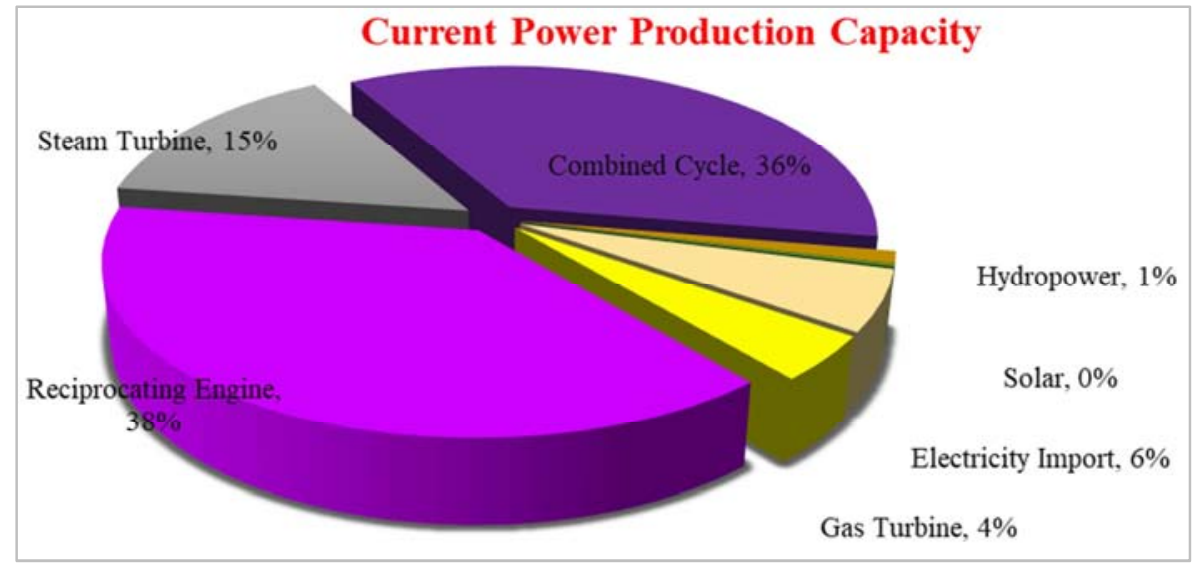

Figure 8. Current Power Generation capacity in Bangladesh.

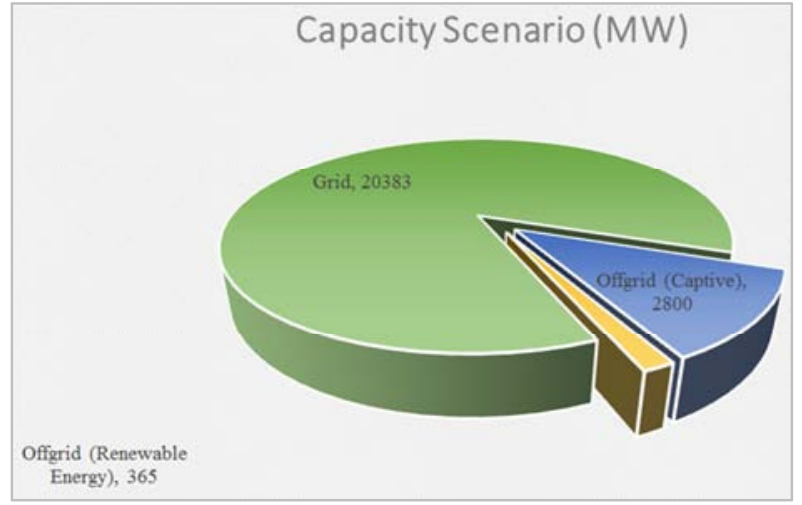

Figure 9. Capacity scenario in Bangladesh.
Table 7. Current Power Production Capacity (Technology wise) [11].

\begin{tabular}{ll}
\hline Power Production Capacity (Technology wise) & Installed Capacity (MW) \\
\hline Gas Turbine & 851 \\
Reciprocating Engine & 7808 \\
Steam Turbine & 2966 \\
Combined Cycle & 7330 \\
Hydropower & 230 \\
Solar & 38 \\
Electricity Import & 1160 \\
Total & 20383 \\
\hline
\end{tabular}




\subsection{Primary Energy Mix for Power Generation at Projected 2030}

Table 8. Primary Energy Mix for Power Generation at Projected 2030 [14].

\begin{tabular}{ll}
\hline Fuel-wise composition (MW) & $\mathbf{2 0 3 0}$ \\
\hline Coal & 17,969 \\
Gas/LNG & 23,744 \\
Liquid & 5,591 \\
Import & 3,496 \\
Nuclear & 2,232 \\
RE (Hydro, Solar, Wind etc.) & 230 \\
Total & 53,262 \\
\hline
\end{tabular}

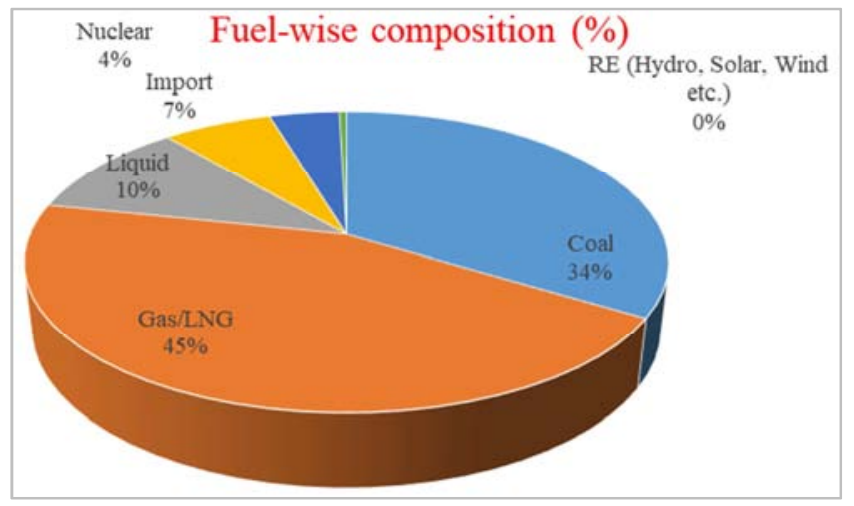

Figure 10. Primary energy Mix for power generation projected -2030 in Bangladesh.

\subsection{By Calculating All These Facts: 2030 Energy Supply Projection Might Be Look Like This}

Table 9. Energy calculation for 2029-30 (MTOE) [14].

\begin{tabular}{llll}
\hline Name & Unit & Quantity & Mtoe \\
\hline Oil (Crude + Refined) & K ton & 12000 & 12.00 \\
LPG & K ton & 2000 & 2.00 \\
Natural Gas & Bcf & 609.92 & 14.14 \\
LNG & Bcf & 730 & 16.93 \\
Coal (Imported) & K ton & 20000 & 12.65 \\
Coal (Local) & K ton & 1000 & 0.63 \\
RE (Hydro) & MW & 230 & 0.17 \\
RE (Solar+wind) & MW & 5000 & 3.69 \\
Electricity (Imported)+Nuclear & MW & 5728 & 4.23 \\
Total Commercial & & & 66.44 \\
Biomass & & & 24.57 \\
Total primary & & & 91.01 \\
\hline
\end{tabular}

Table 10. Primary Energy Mix for Power Generation at Projected 2041 [14].

\begin{tabular}{ll}
\hline Fuel-wise composition (MW) & $\mathbf{2 0 4 1}$ \\
\hline Coal & 25,596 \\
Gas/LNG & 34,165 \\
Liquid & 1,840 \\
Import & 11,996 \\
Nuclear & 5,580 \\
RE (Hydro, Solar, Wind etc.) & 330 \\
Total & 79,507 \\
\hline
\end{tabular}

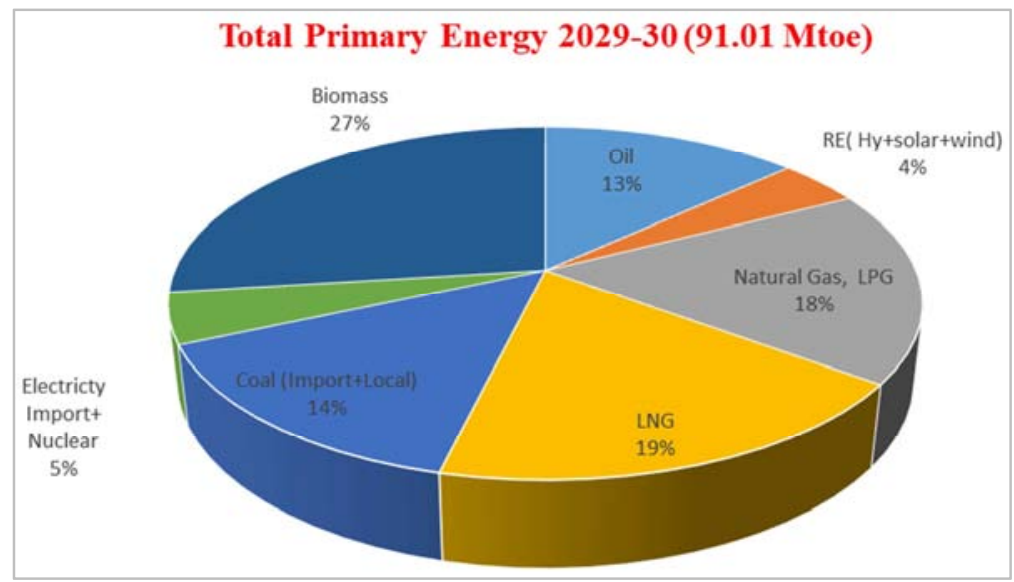

Figure 11. Share of Total Primary Energy (2029-30).

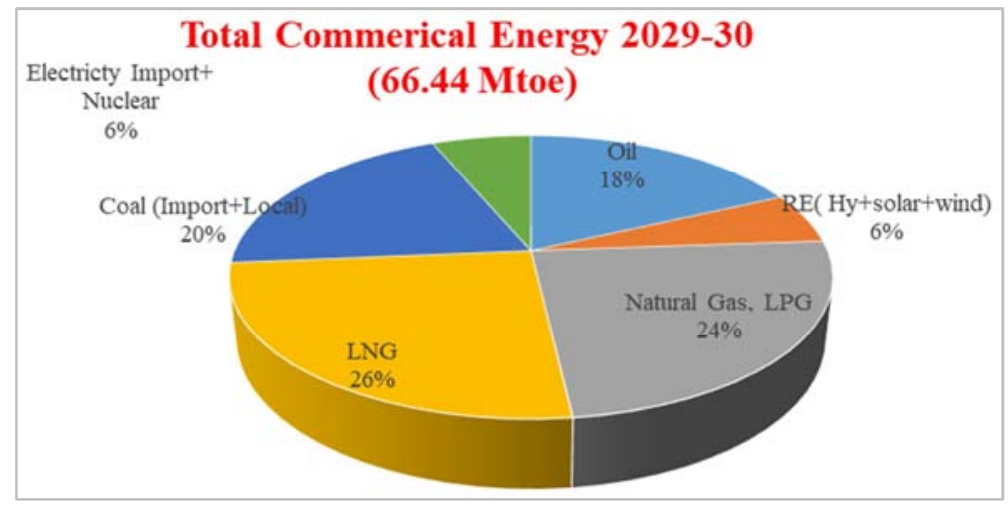

Figure 12. Share of Total Commercial Energy (2029-30). 


\subsection{Primary Energy Mix for Power Generation at Projected 2041}

Table 11. Energy calculation for 2040-41 (MTOE) [14].

\begin{tabular}{llll}
\hline Name & Unit & Quantity & Mtoe \\
\hline Oil (Crude + Refined) & K ton & 16000 & 16.00 \\
LPG & K ton & 3500 & 3.50 \\
Natural Gas & Bcf & 614.66 & 14.25 \\
LNG & Bcf & 730 & 16.93 \\
Coal (Imported) & K ton & 28000 & 17.70 \\
Coal (Local) & K ton & 1000 & 0.63 \\
RE (Hydro) & MW & 230 & 0.17 \\
RE (Solar+wind) & MW & 7500 & 5.54 \\
Electricity (Imported) & MW & 9000 & 6.65 \\
Total Commercial & & & 81.37 \\
Biomass & & & 30.10 \\
Total primary & & & 111.47 \\
\hline
\end{tabular}

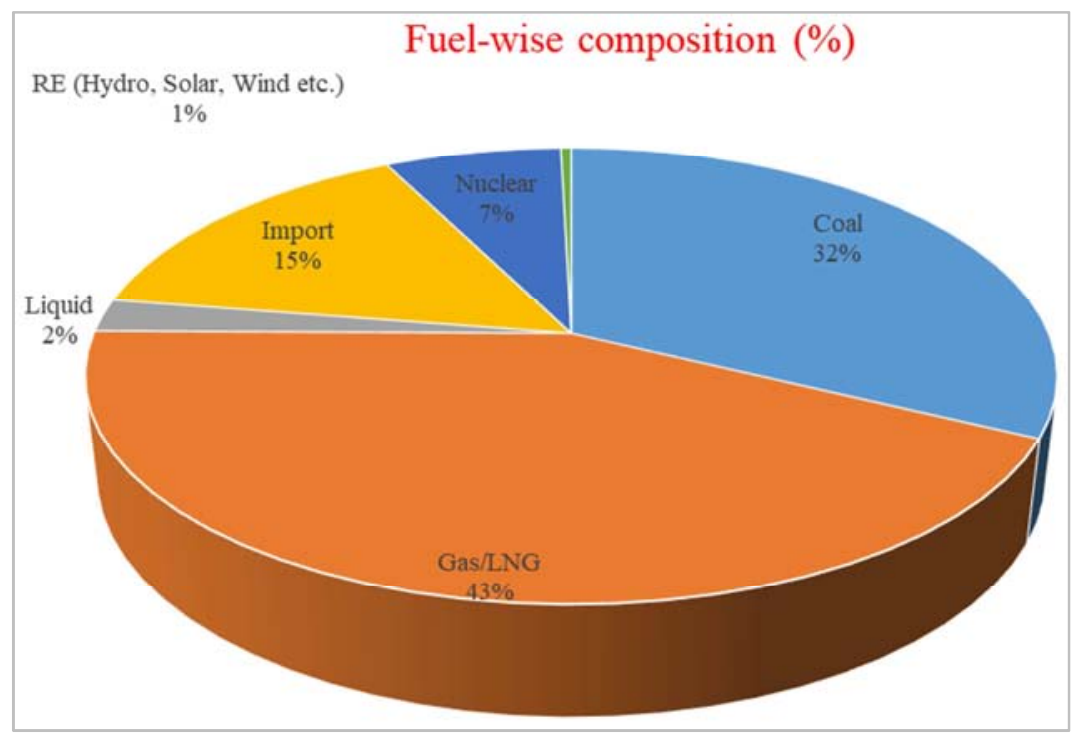

Figure 13. Primary energy Mix for power generation projected -2041 in Bangladesh.

\subsection{By Calculating all These Facts: 2041 Energy Supply Projection Might Be Look Like This}

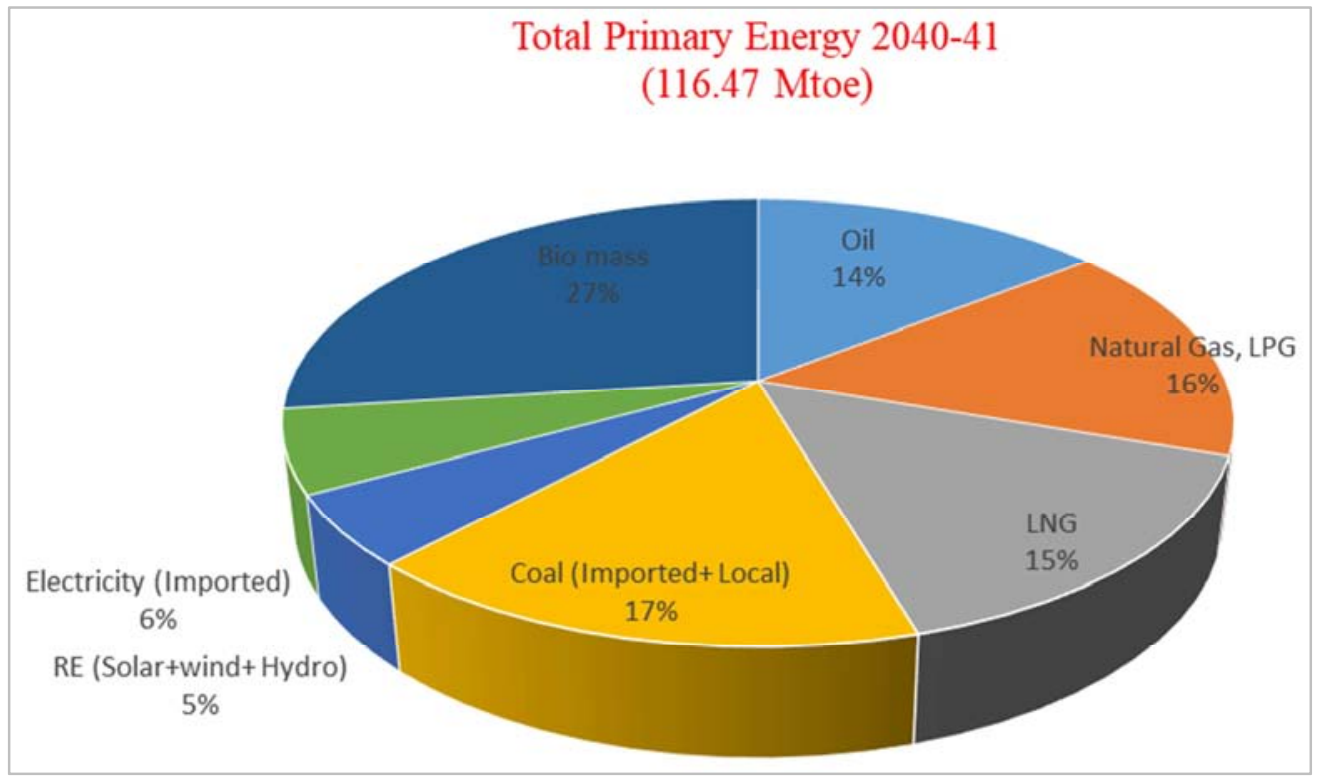

Figure 14. Share of Total Primary Energy (2040-41). 


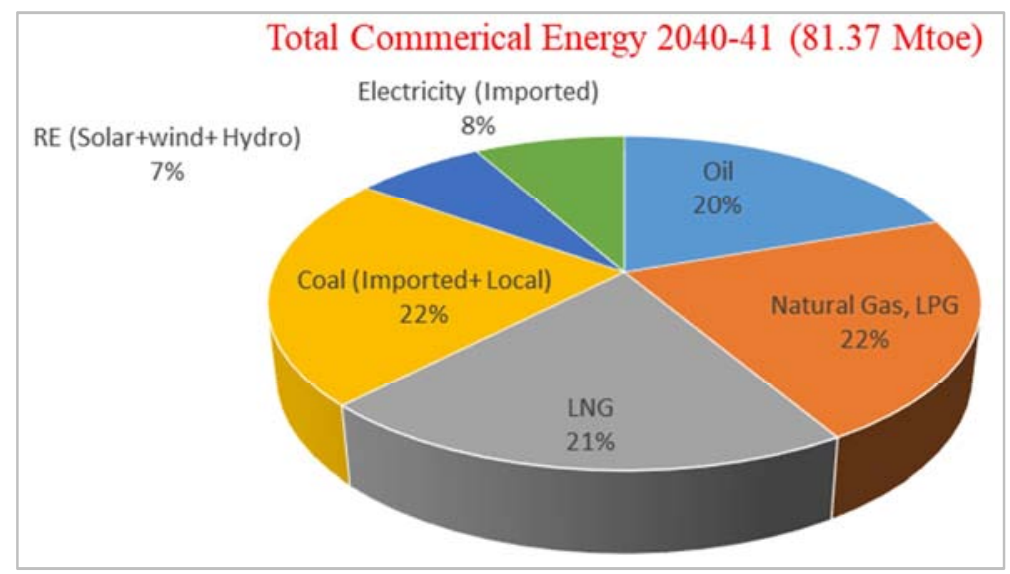

Figure 15. Share of Total Commercial Energy (2040-41).

\subsection{Per Capita Energy Consumption}

Table 12. Per Capita Energy Consumption in Bangladesh [10, 14, 15].

\begin{tabular}{lllll}
\hline FY & Total Commercial Energy (Mtoe) & Total Primary Energy (Mtoe) & Population (Million) & Per Capita Energy (kgoe) \\
\hline $2019-2020$ & 40.52 & 55.50 & 167 & 332.34 \\
$2029-30$ (projection) & 66.44 & 91.01 & 182 & 500.05 \\
$2040-41$ (projection) & 81.37 & 111.46 & 195 & 571.59 \\
\hline
\end{tabular}

\subsection{Per Capita Generation of Electricity}

Table 13. Per Capita Generation of Electricity in Bangladesh [10, 11, 14, 15].

\begin{tabular}{llll}
\hline FY & Net Energy Generation (Gwh) & Population (Million) & Per Capita Generation of Electricity (kWh) \\
\hline $2019-2020$ & 71426 & 167 & 428 \\
$2029-30$ (projection) & 298659 & 182 & 1641 \\
$2040-41$ (projection) & 445824 & 195 & 2286 \\
\hline
\end{tabular}

\section{Challenges for the Implementation of SDGs 2030 and Vision 2041}

(i) Gas Reserve depletion

(ii) Exploration activity in Offshore and Onshore

(iii) Domestic coal Development

(iv) Strategic fit of LNG

(v) Energy efficiency \& Conservation

(vi) Fuel Diversification in Energy Mix

\section{Conclusion}

All the steps have to be taken in view of SDG-2030 and Vision-2041 to reduce natural gas production in a timely manner. Emphasis should be given on domestic resource exploration. According to the PSMP-2016, initiative should be taken to generate a large portion of electricity using coal.

In addition to on-shore natural gas exploration, off-shore exploration activities should also be increased as the coastal area has huge potential. In the case of some existing gas fields, reserves can be increased by using new technology, such as 3D seismic survey.

In order to meet the increasing energy demand, import of LNG, and setting up of LNG terminals have to be implemented in a timely manner. The GSMP need to implement and various steps need to be taken to strengthen the coal sector by revising the new entrepreneur-friendly PSC.

The ERL expansion and SPM project implementation is timely need. Once BPC's ongoing and future projects are implemented, energy security will be enriched for the people of Bangladesh.

Demarcation of the sea with Myanmar and India has opened new horizons in the sea. Cross border energy trade needs to be increased. Considering all the perspectives, we hope that in the near future, Bangladesh will be able to meet its energy demands and ensure uninterrupted energy supply to achieve SDG-2030 and Vision-2041.

\section{Future Recommendation}

(i) Energy efficiency \& Conservation

(ii) Appropriate Energy Mixing

(iii) Reasonable and affordable Energy Pricing

(iv) Stop illegal energy use

(v) Renewable energy

(vi) Gradually reduce Captive power

(vii) Gradually increase import of energy.

\section{Acknowledgements}

I would like to thank Mr. Shihab Mahmud, Assistant 
Director (Reservoir \& Production), Mr. M Alauddin Al Azad, Assistant Director (Operation) and Mr. Md. Nazmul Haque, Assistant Director (Planning), Hydrocarbon Unit, Energy and Mineral Resources Division, Ministry of Power, Energy and Mineral Resources, Bangladesh for his kind support and cooperation.

\section{References}

[1] Imam Badrul. "Energy Resources of Bangladesh" $2^{\text {nd }}$ edition, 2013.

[2] Gustavson Associates, LLC, (2010), Future Scenarios for the Bangladesh Petroleum Sector Development, 31-41.

[3] Gustavson Associates, LLC, (2010), Updated Bangladesh Gas Reserve Estimation, 328-329.

[4] Gustavson Associates, LLC, (2010) Bangladesh Petroleum Potential and Resource Assessment, 4-5, 9, 100-104.

[5] Energy Economics, (2015), Hydrocarbon Unit, Energy and Mineral Resources Division, Ministry of Power, Energy and Mineral Resources, Bangladesh, 14.

[6] Bangladesh Optimal Gas Utilization Study, (2005) Hydrocarbon Unit, Energy and Mineral Resources Division. Ministry of Power, Energy and Mineral Resources, Bangladesh.

[7] Energy efficiency and Conservation Masterplan up to 2030, SREDA, (2015), Power Division, Ministry of Power, Energy and Mineral Resources, Bangladesh, 1-7, 2-7.

[8] Power System Master Plan (2016), Bangladesh Power Development Board, Power Division, Ministry of Power, Energy and Mineral Resources, Bangladesh, 7. 3. 3.
[9] PricewaterhouseCoopers (Pwc). (2013). Minerals Assessment Report in Bangladesh.

[10] Statistical Yearbook of Bangladesh. (2010).

[11] Annual Report on Bangladesh Power Development Board, (2020) Power Division, Ministry of Power, Energy and Mineral Resources, Bangladesh.

[12] Monthly Report on MIS Petrobangla, (2020) Energy and Mineral Resources Division, Ministry of Power, Energy and Mineral Resources, Bangladesh.

[13] Annual Report on Bangladesh Petroleum Corporation, (2020) Energy and Mineral Resources Division, Ministry of Power, Energy and Mineral Resources, Bangladesh.

[14] Revisiting Power System Master plan, (2016), Bangladesh, power Development Board, Power Division, Ministry of Power, Energy and Mineral Resources, Bangladesh, 44-46, 52.

[15] Bangladesh Energy Scenario Report (2020) Hydrocarbon Unit, Energy and Mineral Resources Division, Ministry of Power, Energy and Mineral Resources, Bangladesh.

[16] Choudhury, Z. (2010). Natural Gas Reserve Estimate. Dhaka: Petrobangla, Energy and Mineral Resources Division, Ministry of Power, Energy and Mineral Resources, Bangladesh.

[17] Annual Report on Gas Production, Consumption and Distribution (2020), Hydrocarbon Unit, Energy and Mineral Resources Division, Ministry of Power, Energy and Mineral Resources, Bangladesh, 8, 31 .

[18] Monthly Report on Gas and Coal production (2021) Hydrocarbon Unit, Energy and Mineral Resources Division, Ministry of Power, Energy and Mineral Resources, Bangladesh, $1-2$. 